\title{
Komodifikasi mitos Eyang Sapu Jagad sebagai promosi wisata dan daya tarik pengunjung di Kabupaten Malang
}

\author{
Widi Sukmawati Trisnatul Rohmaa,1, Eggy Fajar Andalas ${ }^{\mathrm{b}, 2^{*}}$ \\ ab Universitas Muhammadiyah Malang, Jalan Raya Tlogomas No. 246, Malang, 65144 , Indonesia \\ ${ }^{1}$ widhiskm17@gmail.com; ${ }^{2}$ eggy@umm.ac.id \\ * Corresponding Author
}

\begin{tabular}{ll}
\hline INFO ARTIKEL & AB \\
\hline Sejarah Artikel: & Diterima: 19 Juli 2021 \\
Direvisi: 2 September 2021 & p \\
Disetujui: 13 September 2021 \\
Tersedia Daring: 31 Oktober \\
2021
\end{tabular}

Kata Kunci:

Daya Tarik Wisata

Dusun Ubalan

Komodifikasi

Mitos Eyang Sapu Jagad

Promosi

ABSTRAK

Mitos Eyang Sapu Jagad adalah sastra lisan milik masyarakat Dusun Ubalan, Kabupaten Malang, Provinsi Jawa Timur. Keberadaan mitos ini penting bagi kehidupan masyarakat karena dianggap memiliki nilai spiritual sekaligus dapat menjadi daya tarik wisata untuk meningkatkan perekonomian masyarakat sekitar. Penelitian ini bertujuan untuk mendeskripsikan transformasi peninggalan Eyang Sapu Jagad sebagai alat promosi dan daya tarik wisata serta memaparkan tipe pengunjung berdasarkan motif yang mendasarinya datang. Penelitian menggunakan desain deskriptif-kualitatif dengan pendekatan sastra pariwisata. Sumber data penelitian ialah informan dari Dusun Ubalan dan berbagai daerah, catatan observasi, dan dokumentasi. Data dikumpulkan dengan teknik wawancara tidak terstruktur, observasi non partisipan, dokumentasi, perekaman, dan pencatatan. Hasil penelitian menunjukkan bahwa petilasan Eyang Sapu Jagad berupa "Sumber Umbulan" yang menjadi daya tarik pengunjung datang melakukan ritual pada malam jumat legi dan bulan Selo, telah dikomodifikasikan oleh pengelola wisata yang terdiri dari masyarakat Dusun Ubalan menjadi wisata religi bernama "Sumber Umbulrejo". Komodifikasi dilakukan dengan menyediakan fasilitas utama seperti pesarean dan bilik mandi untuk melakukan ritual sakral, serta fasilitas pendukung seperti dua kolam renang, destinasi kreatif spot foto, tempat kuliner, akses jalan, lahan parkir, dan loket karcis. Sajian dua fasilitas tersebut mengakibatkan dualitas tipe pengunjung yakni pengunjung pilgrimis dan pengunjung generalis. Dapat disimpulkan adanya komodifikasi tidak menyebabkan hilangnya nilai kesakralan pada mitos, tetapi memperluas jaringan ekonomi-sosial masyarakat sekitar.

\section{ABSTRACT}

Keywords:

Tourist Attraction

Ubalan Village

Commodification

The Myth of Eyang Sapu

Jagad

Promotion

The myth of Eyang Sapu Jagad is an oral literature belonging to the people of Dusun Ubalan, Malang Regency, East Java Province. The existence of myths is important for people's lives because they are considered to have spiritual value as well as being a tourist attraction to improve the economy of the surrounding community.. This study aims to describe the transformation of Eyang Sapu Jagad heritage as a promotional tool and tourist attraction and to describe the types of visitors based on the underlying motive for coming. The research uses a descriptive-qualitative design with a tourism literature approach. Sources of research data are informants from Ubalan Hamlet and various regions, observation notes, and documentation. Data were collected by using unstructured interview techniques, non-participant observation, documentation, recording, and recording. The results showed that the petilasan of Eyang Sapu Jagad in the form of "Sumber Umbulan" which became an attraction for visitors to come to perform rituals on the night of Friday Legi and the month of Selo, had been commodified by the tour manager consisting of the people of Dusun Ubalan into a religious tour 
called "Sumber Umbulrejo". The commodification is carried out by providing main facilities such as boarding and bathing rooms to perform sacred rituals, as well as supporting facilities such as two swimming pools, creative photo spots destinations, culinary places, road access, parking lots, and ticket booths. The presentation of these two facilities resulted in a duality of types of visitors, namely pilgrim visitors and generalist visitors. It can be concluded that the existence of commodification does not cause the loss of the sacred value of the myth, but expands the socio-economic network of the surrounding community.

(C) 2021, Rohma \& Andalas

This is an open access article under CC-BY-SA license

How to Cite: Rohma, W. S. T., \& Andalas, E. F. (2021). Komodifikasi mitos Eyang Sapu Jagad sebagai promosi wisata dan daya tarik pengunjung di Kabupaten Malang. Satwika : Kajian Ilmu Budaya dan Perubahan Sosial, 5(2), 284-302, https://doi.org/10.22219/satwika.v5i2.17440

\section{Pendahuluan}

Malang merupakan salah satu kabupaten yang berada di provinsi Jawa Timur dengan luas $3.530,65 \mathrm{~km}^{2}$ dan jumlah populasi penduduk sekitar 2.654.448 jiwa. Kondisi topografi dataran tinggi yang dikelilingi oleh beberapa pegunungan dan dataran rendah pada ketinggian 250-500 meter di atas permukaan laut menjadikan wilayah ini kaya akan objek pariwisata (BPS, 2021). Sebagian besar objek wisata di wilayah Malang merupakan wisata alam. Wisata alam ini berbasis kebudayaan lokal masyarakat, salah satunya berupa mitos.

Mitos adalah cerita rakyat yang dipercaya keberadaannya dan dinilai suci oleh masyarakat yang memilikinya (Andalas, 2015; Aristama et al., 2020; Pratiwi et al., 2018; Sulistyorini \& Andalas, 2017). Mitos merupakan bagian dari sastra lisan yang memiliki keterkaitan erat dengan tempat wisata dan mampu berperan besar dalam sektor pariwisata di Indonesia (Effendy, 2019; Abdullah \& Panghastuti, 2018; Febriyanto et al., 2018). Kondisi tersebut disebabkan karena mitos dipercaya meninggalkan jejak positif yang dapat mempengaruhi kehidupan masyarakat pemiliknya untuk menyakralkan dan mengembangkan petilasan yang muncul dari mitosnya. Dengan adanya tindakan tersebut, secara langsung maupun tidak langsung menjadikan sastra lisan berupa mitos sebagai salah satu modal yang turut menyumbang industri pariwisata.

Salah satu destinasi wisata di wilayah Kabupaten Malang yang menggunakan mitos sebagai daya tarik adalah wisata lokal pemandian "sumber umbulan" yang berada di Dusun Ubalan, Kecamatan Ngajum, Provinsi Jawa Timur. Pemandian "sumber umbulan" muncul akibat dari adanya mitos masyarakat kepada sosok yang dianggap sakti bernama Eyang Sapu Jagad. Masyarakat percaya bahwa Eyang Sapu Jagad adalah seorang yang sakti karena masih berdarah keraton berasal dari Mataram. Bagi masyarakat Dusun Ubalan, Eyang Sapu Jagad adalah orang yang berjasa untuk kehidupan mereka karena Eyang telah menciptakan sumber air yang dianggap sakti dapat menghadirkan banyak berkah. Masyarakat setempat percaya bahwa sumber air umbulan yang diciptakan Eyang memiliki kekuatan ghaib dapat membuat hasil panen mereka melimpah, menyembuhkan beragam penyakit, menaikkan jabatan, dan mendatangkan banyak rezeki.

Dengan adanya kepercayaan yang tumbuh menjadikan "sumber umbulan" kian tahun semakin ramai dikunjungi masyarakat dalam dan luar Dusun Ubalan 
untuk memanjatkan segala hajatnya melalui perantara Eyang Sapu Jagad. Apalagi pada hari-hari tertentu seperti Juma'at legi dan bulan selo yang dalam kalender masehi jatuh pada bulan Juni, sumber ini semakin ramai dikunjungi. Oleh karena semakin banyak pengunjung yang berdatangan karena tertarik dengan mitosnya, keberadaan "sumber umbulan" dikomodifikasikan masyarakat setempat menjadi destinasi wisata pemandian dengan nama "Sumber Umbulrejo". Adanya komodifikasi tersebut membuktikan bahwa mitos telah menjadi daya tarik masyarakat sehingga digunakan sebagai strategi promosi dalam menggerakkan industri pariwisata (Agfianto et al., 2019; Suhamdi et al., 2010).

Fakta di atas sesuai dengan pandangan Putra (2019) bahwa pada dasarnya sastra dan pariwisata memiliki hubungan yang sangat erat. Hubungan itu terlihat dari kenyataan bahwa sastra mampu memberikan kontribusi dalam mempromosikan pariwisata. Kontribusi karya sastra dalam mengembangkan pariwisata baik secara langsung maupun tidak telah berlangsung sejak lama, lebih dari satu setengah dekade. Peran sastra dalam mengembangkan pariwisata Indonesia melalui banyak cara, yaitu festival sastra, novel yang mempromosikan berbagai daerah dalam latar ceritanya, dan mitos yang dimanfaatkan sebagai branding destinasi wisata.

Pandangan di atas membuktikan bahwa keberadaan mitos Eyang Sapu Jagad di Dusun Ubalan berkontribusi dalam mengembangkan destinasi wisata pemandian berupa "sumber umbulrejo". Adanya sumber umbulan telah dimanfaatkan sebagai produk utama dalam pengembangan wisata lokal dan menjadi daya tarik tersendiri bagi beragam pengunjung yang datang. Untuk itu, penelitian ini bertujuan 1) mendeskripsikan transformasi peninggalan Eyang Sapu Jagad sebagai alat promosi dan daya tarik wisata di Dusun Ubalan Kabupaten Malang, dan 2) memaparkan tipe pengunjung berdasarkan motif yang mendasarinya datang ke wisata "sumber umbulrejo" di Dusun Ubalan Kabupaten Malang.

Berdasarkan penelusuran peneliti, dalam kaitan antara sastra dan pariwisata terdapat hubungan yang erat. Penelitian terdahulu menunjukkan bahwa sastra dapat menjadi alat bagi promosi ataupun pengembangan wisata di suatu wilayah (Renold et al., 2020; Anoegrajekti dan Imawati 2020; Artawan (2020); Jefrika 2020). Dalam penelitiannya, Renold et al., (2020) menunjukkan bahwa mitos dan sejarah berperan penting dalam meningkatkan kunjungan wisatawan ke tempat-tempat wisata yang berlatar belakang mitos seperti 1) Kolam Bidadari yang berada di Kabupaten Pangkep, 2) Air Terjun Ketemu Jodoh di Kabupaten Goa, Kete Kesu di Kabupaten Tana Toraja, serta bangunan bersejarah seperti 1) Bunker Jepang di Delta Lakkang, Makassar, dan 2) Makam Raja Tallo. Wisatawan menganggap dengan mengunjungi wisata mitos akan mendapatkan kehidupan yang lebih baik. Anoegrajekti dan Imawati (2020) juga menunjukkan bahwa cerita Sri Tanjung Sidopekso sebagai legenda asalusul Banyuwangi, telah mendukung sektor pariwisata karena mengalami perubahan dari legenda menjadi syair khas lagu Banyuwangi, produk buku cerita, lakon teater tradisional Janger, dan fesyen internasional BEC. Tidak berbeda, Artawan (2020) menunjukkan bahwa novel Aku Cinta Lovina memiliki hubungan resiprokal antara sastra dengan pariwisata, yaitu penulis mempromosikan destinasi wisata di Lovina dengan menggunakan latar cerita Bali Utara untuk menggambarkan kisah percintaan antara pegawai hotel dan wisatawan. Hubungan timbal balik tampak melalui penulis sendiri yang terinspirasi menciptakan novel tersebut karena melihat perkembangan Lovina sejak tahun 70-an semakin pesat. Jefrika (2020) menunjukkan bahwa dalam novel Siti Nurbaya mengambarkan objek-objek wisata di Kota Padang meliputi pantai, gunung, taman, dan 
perkampungan modern di sekitar sungai Batang Arau. Adapun pengaruh novel terhadap perkembangan wisata di kota Padang terlihat dari kegiatan dan objek wisata baru seperti (1) Festival Siti Nurbaya, (2) Taman Siti Nurbaya, (3) Jembatan Siti Nurbaya, dan (3) Kuburan Siti Nurbaya.

Meskipun hubungan antara sastra dan pariwisata sudah mendapat perhatian oleh peneliti terdahulu, tetapi fakta keberagaman motif pengunjung yang datang ke tempat wisata dan adanya unsur transformasi pada keberadaan objek sebagai akibat adanya motif pariwisata, khususnya dalam sastra lisan, belum didiskusikan. Karenanya, penelitian ini penting dilakukan karena beberapa alasan sebagai berikut. Pertama, dari keempat penelitian di atas membuktikan bahwa tempat-tempat wisata di berbagai daerah memiliki keterkaitan erat dengan karya sastra. Hadirnya karya sastra tidak hanya memberikan nilai pengajaran bagi kita, namun juga berkontribusi besar dalam praktik pariwisata. Untuk itu, mitos Eyang Sapu Jagad di Dusun Ubalan perlu diteliti secara mendalam agar mengetahui proses metamorfosisnya dan memahami cara kerja sastra menyumbang ekonomi sektor pariwisata. Kedua, keberadaan mitos Eyang Sapu Jagad yang menjadi daya tarik wisata di Dusun Ubalan, Kabupaten Malang ini masih baru dikembangkan menjadi destinasi wisata, untuk itu hasil penelitian ini diharapkan dapat turut mempromosikan wisata religi ini agar keberadaannya semakin dikenal masyarakat luas. Ketiga, pada faktanya sastra dapat memberikan pengaruh terhadap keberadaan pariwisata. Seperti yang dikemukakan oleh Aneograjekti dan Imawati (2020) di Irlandia sastra telah digunakan sebagai daya tarik wisata sejak tahun 1980 an. Pada masa itu, Irlandia menjadi negara yang dikunjungi wisatawan karena adanya karya sastra yang menjadi motor penggerak di dalamnya. Dengan memanfaatkan karya sastra yang tumbuh, negara Irlandia mengembangkannya menjadi destinasi wisata dan melayani wisatawan dengan baik serta memperbaiki infrastruktur jalan untuk memudahkan aksesbilitas. Dalam konteks Indonesia, keberadaan mitos Eyang Sapu Jagad ini juga digunakan sebagai daya tarik wisata pemandian "sumber umbulrejo" sehingga penelitian ini penting dilakukan untuk mengetahui keberpengaruhan sastra terhadap pariwisata. Keempat, penelitian mengenai hubungan sastra dan pariwisata khususnya sastra lisan masih jarang dilakukan, padahal faktanya sastra dan pariwisata memiliki hubungan resiprokal yang saling menguntungkan sejak lama Putra (2019).

Berangkat dari permasalahan di atas, Putra (2019) mengemukakan pendekatan sastra pariwisata dengan mengadopsi kajian pariwisata atas fenomena sastra di Eropa dan Cina yang dilakukan oleh beberapa ahli seperti David Herbert, Hoppen, Busby \& Klug, Anne, Lorraine Brown, Alan Fyall, dan $\mathrm{Yu} \& \mathrm{Xu}$. Dengan meminjam pandangan para ahli tersebut, Putra mengemukakan bahwa pendekatan sastra pariwisata di Indonesia dibagi dalam empat kategori sebagai berikut. Pertama, kajian tematik pariwisata sastra. Kedua, mengkaji tokoh, aktivitas, dan tempat-tempat sastra yang berkontribusi pada sektor industri pariwisata. Ketiga, kajian aktivitas yang melibatkan sastra. Keempat, kajian transformasi karya sastra ke dalam bentuk lain dan promosi pariwisata. Sehubungan dengan hal itu, kajian ini difokuskan pada analisis tokoh-tokoh, aktivitas, dan tempattempat sastra yang berkontribusi pada sektor industri pariwisata. Dalam kajian ini analisis berfokus pada sastrawan dan tempat-tempat atau benda peninggalan yang menjadi terkenal karena karya sastranya.

Sehubungan dengan hal di atas, permasalahan dalam kajian ini akan diselesaikan dengan teori sastra pariwisata yang digagas oleh David Herbert. Menurut Herbert (2001) tempat-tempat sastra yang berhubungan dengan penulis dapat digunakan sebagai koneksi untuk mempromosikan destinasi wisata dan menarik pengunjung. Tempat-tempat sastra dan peninggalannya pasti memiliki daya 
tarik yang kuat sehingga dapat dikembangkan menjadi destinasi wisata dan mampu menarik beragam pengunjung. Dalam hal ini Herbert merumuskan fokus kajian sebagai berikut. (1) Analisis sastrawan dan tempat peninggalan/karyakaryanya yang menjadi daya tarik wisata. (2) Analisis tipe pengunjung yang meliputi, (a) pengunjung pilgrimis (memiliki minat \& pengetahuan khusus terhadap objek yang dikunjungi, dan (b) pengunjung generalis (tanpa memiliki pengetahuan khusus terhadap objek yang dikunjungi).

Karya sastra yang berkembang di berbagai daerah telah banyak yang digunakan sebagai alat promosi wisata. Sastra berkontribusi besar dalam memainkan perannya untuk mendukung sektor pariwisata. Seperti halnya Mitos Eyang Sapu Jagad yang meninggalkan petilasan berupa "sumber umbulan" telah menjadi daya tarik masyarakat setempat sehingga digunakan sebagai alat promosi dengan dikembangkannya "sumber umbulan" menjadi wisata pemandian yang dilengkapi dengan berbagai fasilitas di dalamnya. Dengan demikian, teori yang dikemukakan Herbert, dinilai sangat relevan untuk membantu peneliti menemukan fakta tentang sastrawan dan peninggalannya yang menjadi daya tarik wisata serta mengetahui berbagai tipe pengunjung berdasarkan motif yang mendasarinya datang ke wisata religi pemandian "Umbulrejo" di Dusun Ubalan, Kabupaten Malang.

\section{Metode}

Penelitian ini merupakan penelitian kualitatif deskriptif dengan menggunakan pendekatan sastra pariwisata yang ditekankan pada analisis tokoh-tokoh, aktivitas, dan tempat-tempat sastra yang berkontribusi pada sektor industri pariwisata. Penelitian dilakukan selama tiga bulan, yaitu April-Juni 2021 di Dusun Ubalan, Kabupaten Malang, Jawa Timur. Sumber data penelitian ini ialah 1) informan, 2) catatan lapang saat observasi, dan 3) dokumentasi hasil pemotretan.
Informan yang digunakan berjumlah tujuh orang di antaranya yaitu Bapak Suharto berusia 71 tahun (penduduk asli Dusun Ubalan selaku juru kunci di "sumber umbulan"), Bapak Fani berusia 47 tahun (penduduk asli Dusun Ubalan yang menjabat sebagai pengelola wisata pemandian "sumber umbulrejo"), dan kelima informan lainnya merupakan pengunjung wisata pemandian "sumber umbulan" dengan berbagai latar belakang, usia, dan tujuan yang berbeda, di antaranya Ibu Sutiyah (68 tahun), Ibu Siti Masruroh (44 tahun), Mbak Sintia (24 tahun), Mbak Ayu (30 tahun), dan Mas Arif (21 tahun).

Pengumpulan data dilakukan dengan cara; 1) wawancara tidak terstruktur, 2) observasi non partisipan, 3) dokumentasi, 4) perekaman, dan 5) pencatatan. Pertama, teknik wawancara tidak struktur dilakukan dengan cara mengajukan pertanyaan secara spontan kepada tujuh informan yang berhubungan erat dengan wisata pemandian "sumber umbulan" diantaranya juru kunci, pengelola wisata, dan lima pengunjung yang datang dengan beragam motif. Kedua, observasi non-partisipan dilakukan dengan cara peneliti turun langsung ke area untuk mengamati lokasi penelitian berupa "sumber umbulan" sebagai petilasan Eyang Sapu Jagad yang dijadikan sebagai daya tarik wisata. Ketiga, teknik dokumentasi dilakukan untuk memotret berbagai data yang menunjang penelitian meliputi, (1) informan, (2) lokasi penelitian, (3) petilasan Eyang Sapu Jagad berupa sumber, dan (4) berbagai fasilitas di wisata "sumber umbulrejo". Keempat, perekaman dilakukan untuk merekam proses wawancara menggunakan digital etnografi. Kelima, teknik pencatatan dilakukan untuk mencatat berbagai informasi penting terkait hubungan mitos Eyang Sapu Jagad dengan wisata pemandian "sumber umbulan".

Teknik analisis data dilakukan dengan memadukan teknik strategi pengalihan wacana yang dicetuskan oleh Sudikan (2001) untuk menganalisis transformasi peninggalan Eyang Sapu Jagad sebagai alat promosi dan daya tarik wisata serta analisis terhadap tipe 
pengunjung berdasarkan motif yang mendasarinya datang ke wisata "sumber umbulrejo" di Dusun Ubalan, Kabupaten Malang. Tahapan analisis data dalam penelitian ini, meliputi 1) data dari hasil rekaman wawancara ditranskrip dalam bahasa tulis secara kasar tanpa memperhatikan tanda bacanya, 2) data-data hasil transkrip disatupadukan dan disesuaikan dengan hasil rekaman, 3) setelah itu memperbaiki transkrip dan memberi tanda baca pada kata serta kalimat yang terkesan asing dan kurang jelas, 4) kemudian melakukan pengetikan dari hasil transkrip yang telah diperbaiki, 5) setelah pengetikan selesai, berbagai bahasa yang digunakan dalam wawancara diubah dalam bahasa Indonesia, dan 6) setelah data-data hasil transkrip terkumpul dalam wujud tulisan bahasa Indonesia, lalu dikategorisasikan untuk dianalisis terkait transformasi peninggalan Eyang Sapu Jagad sebagai alat promosi dan daya tarik wisata serta analisis terhadap tipe pengunjung berdasarkan motif yang mendasarinya datang ke wisata "sumber umbulrejo" di Dusun Ubalan, Kabupaten Malang.

\section{Hasil dan Pembahasan}

Kajian penelitian ini membahas tentang komodifikasi mitos Eyang Sapu Jagad sebagai promosi wisata dan daya tarik pengunjung di Dusun Ubalan, Kabupaten Malang. Fokus penelitian ini pada ranah kajian sastra pariwisata mengenai analisis tokoh sastrawan, aktivitas, dan tempat atau peninggalan yang menjadi terkenal karena karya sastranya. Seperti yang disampaikan di atas bahwa sastra dan pariwisata memiliki hubungan yang sangat erat. Hubungan ini terlihat dari peran sastra yang mampu memberikan kontribusi dalam mempromosikan pariwisata. Untuk memperjelas konteks penelitian mengenai komodifikasi mitos Eyang Sapu Jagad, disajikan beberapa sub pembahasan mengenai cerita asal usul mitos sebagai produk komoditas, proses komodifikasi mitos sebagai alat promosi dan daya tarik wisata, dan mendeskripsikan beragam pengunjung yang datang dengan berbagai motif.

\subsection{Cerita Asal Usul Mitos Eyang Sapu Jagad sebagai Produk Komoditas}

Mitos Eyang Sapu Jagad adalah hasil kebudayaan lokal milik dua masyarakat yaitu Dusun Ubalan dan Desa Maguan. Keberadaan mitos milik dua daerah ini muncul pada tahun 1930-an. Mitos ini ditokohi oleh seorang yang bernama asli Raden Aryo Tumenggung Notodiningrat III atau yang kerap disebut Eyang Sapu Jagad. Sosok Eyang Sapu Jagad ini merupakan pendatang dari keraton Mataram Yogyakarta. Mitos Eyang Sapu Jagad yang hidup di dua daerah ini disebabkan karena kisah pelarian Eyang Sapu Jagad dari kejaran Belanda. Menurut wawancara dengan informan, Eyang merupakan sosok yang berpengaruh besar terhadap keberadaan Belanda di Indonesia. Waktu itu, pada saat Eyang Sapu Jagad melawan Belanda, beliau terdesak hingga akhirnya bersama satu santrinya yang bernama mbah Dipo melarikan diri ke Desa Maguan, Kecamatan Ngajum, Kabupaten Malang (wawancara dengan Pak Suharto, 8 Mei 2021 di Dusun Ubalan).

Desa Maguan termasuk dalam satu wilayah kelurahan dengan Dusun Ubalan. Letak Dusun Ubalan secara lebih rinci berada tepat di barat Desa Maguan. Karena hal itulah keberadaan mitos Eyang Sapu Jagad yang muncul di Desa Maguan ini memberikan pengaruh besar terhadap kehidupan masyarakat Dusun Ubalan. Pada mulanya, kedatangan Eyang Sapu Jagad di Desa Maguan disambut ramah oleh warga setempat karena masyarakat memandang Eyang sebagai sosok sakti berasal dari Mataram yang berdarah keraton. Masyarakat Desa Maguan sampai bersedia membantu Eyang membuat rumah persinggahan di desa ini untuk mengamankan dirinya dari kejaran Belanda.

Selama tinggal di Desa Maguan, Eyang Sapu Jagad selalu mengajarkan kebaikan pada masyarakat setempat hingga banyak masyarakat yang nyantrik atau berguru 
padanya. Oleh karena banyak masyarakat yang nyantrik ke rumah Eyang, sampailah berita ini ke tetangga sebelah Desa Maguan yaitu Dusun Ubalan. Tidak lama setelah mendengar berita tersebut, banyak sekali masyarakat Dusun Ubalan yang berbondong-bondong untuk menyantrik juga ke rumah Eyang Sapu Jagad di Desa Maguan. Dari hasil nyantrik masyarakat Desa Maguan dan Dusun Ubalan ke Eyang Sapu Jagad, banyak sekali perubahan positif perilaku masyarakat, baik dari segi sosial maupun spiritualnya.

Seiring berjalannya waktu, Desa Maguan dan Dusun Ubalan tiba-tiba mendapati bencana kekeringan air yang membuat masyarakat dua daerah ini sangat kebingungan karena mayoritasnya bekerja sebagai petani sehingga mengalami kesulitan untuk mengairi sawah-sawah mereka. Melihat keadaan ini, Eyang Sapu Jagad yang dipercaya sebagai orang sakti, seketika menciptakan sumber yang begitu deras di Dusun Ubalan. Alasan Eyang menciptakan sumber di Dusun Ubalan karena letak wilayahnya sangat strategis sehingga air sumbernya dapat mengalir ke segala penjuru arah, termasuk Desa Maguan (wawancara dengan Pak Suharto, 8 Mei 2021 di Dusun Ubalan).

Keberadaan sumber di Dusun Ubalan tersebut diberi nama "sumber umbulan" oleh warga setempat karena airnya selalu meluap dengan deras yang dalam bahasa Jawa disebut dengan mumbul-mumbul. Adanya "sumber umbulan" yang diciptakan Eyang ini dipercaya masyarakat setempat memiliki kekuatan magis tinggi karena sawah-sawah masyarakat yang dialiri air sumber menghasilkan panen yang sangat melimpah, jauh dari hasil panen sebelumnya. Karena kepercayaan tersebut, masyarakat menjadikan "sumber umbulan" sebagai sumber keberkahan. Segala kesulitan, penderitaan, dan musibah yang dialami masyarakat, dilarikan ke "sumber umbulan" karena mereka menganggap sumber tersebut ajang pemberi solusi. Dalam hal ini masyarakat meminta kesembuhan penyakitnya dan disingkirkan dari segala bahaya yang menimpanya dengan berpacuan lantaran Eyang Sapu Jagad yang tidak lain adalah si pembuat sumber yang dianggap sakti. Oleh karena kepercayaan-kepercayaan yang tumbuh itulah keberadaan "sumber umbulan" di Dusun Ubalan dikeramatkan sebagai petilasan sakral.

Adanya kepercayaan masyarakat Dusun Ubalan terhadap kekuatan magis di "sumber umbulan" ini lambat laun mulai menjalar ke masyarakat luar dusun. Oleh karena hal tersebut, keberadaan "sumber umbulan" mulai didatangi penduduk luar Dusun Ubalan sekitar tahun 1932-an. Kedatangan masyarakat luar Dusun Ubalan tersebut, menurut pengakuan Bapak Suharto, didasari oleh rasa penasarannya ingin membuktikan daya magis yang muncul dari sumber dengan cara memanjatkan doa seperti meminta kesembuhan, kesaktian, dan kenaikan pangkat. Mengenai hal ini sesuai dengan yang disampaikan informan sebagai berikut.

\begin{abstract}
"Pas niku sekitar tahun 1932-an sumber umbulan niki mulai dikenal masyarakat luar Dusun Ubalan, niki kulo angsal crito dugi mbah kulo lek tiyang-tiyang sing ten sumber pas niku wonten sing nedi pengobatan, kerjone ben pangkate luweh diduwurne, lan kesaktenan nggih wonten."
\end{abstract}

"Pada saat itu, sekitar tahun 1932-an, keberadaan "sumber umbulan" ini mulai dikenal masyarakat luar Dusun Ubalan. Ini saya dapat cerita dari kakek saya, kalau orang luar yang datang ke sumber saat itu ada yang meminta kesembuhan, kenaikan pangkat, dan juga kesaktian." (wawancara dengan Pak Suharto, 8 Mei 2021 di Dusun Ubalan).

Berdasarkan asal usul mitos Eyang Sapu Jagad terdapat tindakan masyarakat Dusun Ubalan yang menyakralkan "sumber umbulan" karena percaya bahwa sumber tersebut memiliki daya magis yang tinggi, 
membuktikan bahwa mitos tersebut memiliki peran penting. Kondisi ini sesuai pandangan Humaeni (2018) bahwa mitos dapat dijadikan simbol pengukuhan dan kekuasaan sakral dalam menjalankan hidup bermasyarakat dengan berbagai aktivitas, seperti keagamaan, sosial, politik, bahkan ekonomi. Pandangan tersebut sama dengan perilaku masyarakat Dusun Ubalan yang menggunakan mitos sebagai simbol kesakralan dalam menjalankan kehidupan spiritualnya. Mitos telah menjadi hal berharga karena dianggap memiliki nilai yang bermakna sehingga mampu memikat masyarakat untuk mengukuhkan keberadaannya.

Tindakan masyarakat Dusun Ubalan yang selalu datang ke "sumber umbulan" untuk memanjatkan segala hajatnya, membuktikan bahwa mitos sebagai hasil karya sastra memiliki daya pikat tersendiri sehingga mampu menarik masyarakat datang ke sumber. Kondisi yang sedemikian menurut Busby \& Klug (2001) disebut sebagai aktivitas wisata yang berpedoman pada karya sastra sebagai daya tariknya. Pandangan ini sesuai dengan keberadaan mitos Eyang Sapu Jagad di Dusun Ubalan yang semakin berkembang sehingga mampu menarik banyak masyarakat dalam dan luar Dusun Ubalan datang ke lokasi yang berkaitan dengan sastrawan yang menokohi mitos tersebut.

Pendapat di atas sejalan dengan temuan ahli China yaitu Yu dan Xu (2016) yang menyatakan bahwa berbagai karya sastra, salah satunya puisi di Cina dapat dikategorikan sebagai sajian pariwisata yang menawarkan warisan budaya. Dalam konteks Indonesia, mitos Eyang Sapu Jagad ini juga termasuk salah satu wujud karya sastra hasil warisan budaya yang dapat menjadi alat penggerak tempat sastra. Mitos berfungsi sebagai daya tarik yang secara tidak langsung menduniakan tempat sastra berupa petilasan "sumber umbulan". Oleh karena hal tersebutlah keberadaan mitos Eyang Sapu Jagad di Dusun Ubalan berpotensi sebagai produk warisan budaya yang dapat dikomodifikasikan.

Mitos berpotensi sebagai produk komoditas karena mengandung nilai jual yang sangat tinggi. Hal tersebut sesuai dengan temuan penelitian Renold et al., $\underline{(2020)}$ bahwa suatu mitos dengan peran sejarah besar dibaliknya dapat menjadi komoditas wisata sehingga mampu meningkatkan jumlah pengunjung yang datang. Masyarakat mengunjungi tempat mitos dengan harapan terjadi perubahan baik dalam hidupnya. Hal ini selaras dengan daya tarik pengunjung ke "sumber umbulan" karena percaya mitos yang hidup mampu memenuhi kebutuhan mereka.

Harapan masyarakat terhadap mitos Eyang Sapu Jagad dengan berkunjung ke petilasan "sumber umbulan" di Dusun Ubalan, Kabupaten Malang dapat dikatakan sebagai tahap awal konsumsi dengan meminjam peran sastra lisan. Hal inilah yang menjadi peluang para kaum elit memanfaatkan produk budaya masyarakat untuk dikonsumsi dalam wujud kreasi atau dikomodifikasi menjadi hal yang lebih bernilai (Baudrilliard, 2012).

\subsection{Proses Komodifikasi Petilasan} "Sumber Umbulan" sebagai Alat Promosi dan Daya Tarik Wisata Religi di Dusun Ubalan

Keberadaan "sumber umbulan" di Dusun Ubalan, Kabupaten Malang sebagai petilasan Eyang Sapu Jagad telah dikenal masyarakat luar dusun tersebut sejak tahun 1932-an. Hasil wawancara dengan Pak Suharto selaku juru kunci di "sumber umbulan", adanya masyarakat yang datang ke sumber saat itu masih berasal dari daerah sekitar Dusun Ubalan yang artinya pengunjung dari tetangga dusun itu sendiri. Masyarakat yang datang ke sumber telah mempercayai adanya kekuatan magis yang tumbuh karena mitos Eyang Sapu Jagad, sehingga membuat mereka datang dengan 
berbagai hajat seperti meminta kesaktian, kesembuhan dari penyakitnya, awet muda, naik jabatan dalam pekerjaannya, dan dilancarkan usahanya.

Masyarakat yang datang ke sumber waktu itu melantunkan hajatnya dengan sangat bervariasi seperti ada yang memanjatkan doanya di sebelah sumber, melakukan ritual mandi di sumber, menabur bunga, bahkan ada yang menyalakan dupa di pohon beringin dekat sumber. Keberagaman cara yang dilakukan masyarakat pada waktu itu, membuat keadaan "sumber umbulan" menjadi tidak sedap dipandang karena tidak adanya seseorang sebagai pengatur di dalamnya. Melihat keadaan tersebut, masyarakat Dusun Ubalan menunjuk seseorang bernama Mbah Gimbal sebagai juru kunci "sumber umbulan" untuk mengatur ketertiban masyarakat yang datang (wawancara dengan Pak Suharto, 8 Mei 2021 di Dusun Ubalan).

Semenjak adanya juru kunci yang mengatur "sumber umbulan", lambat laun kondisi sumber menjadi semakin ramai dikunjungi karena mulai banyak hajat masyarakat yang dikabulkan, sehingga mampu menarik masyarakat lain untuk datang ke sumber. Banyaknya masyarakat luar Dusun Ubalan yang datang waktu itu tidak hanya disebabkan karena kepercayaannya terhadap khasiat sumber umbulan yang memiliki daya magis, namun juga didukung oleh tidak adanya pembatasan kunjungan dan juga tidak ada penarikan apa pun dari masyarakat Dusun Ubalan. Oleh sebab itulah, setiap harinya pasti selalu ada masyarakat luar Dusun Ubalan yang datang entah satu atau dua orang. Kondisi yang sedemikian terus berlanjut sampai tahun 1990-an (wawancara dengan Pak Suharto, 1 Juni 2021 di Dusun Ubalan).

Pada saat tahun 1990-an, petilasan sakral "sumber umbulan" mengalami perubahan sangat drastis, karena tidak hanya satu atau dua orang yang berkunjung setiap harinya, melainkan lebih dari 10 orang yang mayoritasnya berasal dari
Malang kota. Bahkan ada pula yang berasal dari luar Kabupaten Malang yakni Surabaya dan Pasuruan. Oleh karena banyaknya pengunjung yang datang, masyarakat Dusun Ubalan bekerjasama membuat pesarean kecil (gambar 1) dan bilik penutup (gambar 2). Adanya pesarean yang dibuat tersebut diperuntukkan agar masyarakat yang mengunjungi sumber dapat menggunakannya untuk melakukan ritual doa dengan khusyuk, sementara bilik penutup sumber diciptakan untuk mendukung kenyamanan masyarakat yang melakukan ritual mandi. Terkait itu, berikut disajikan bukti adanya kedua tempat tersebut.

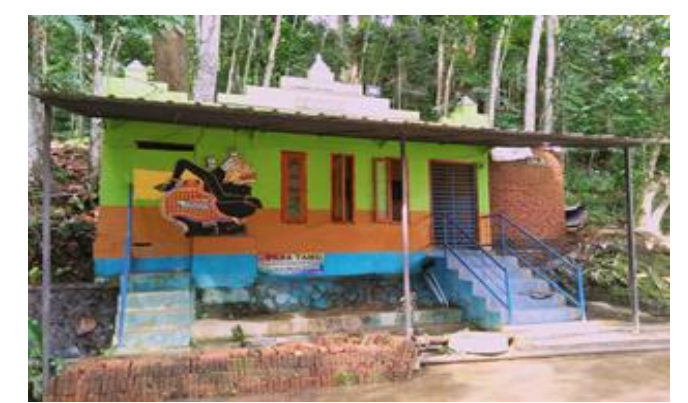

Gambar 1 Pesarean sebagai tempat berdoa di "Sumber Umbulan (Sumber: Dokumentasi Pribadi)

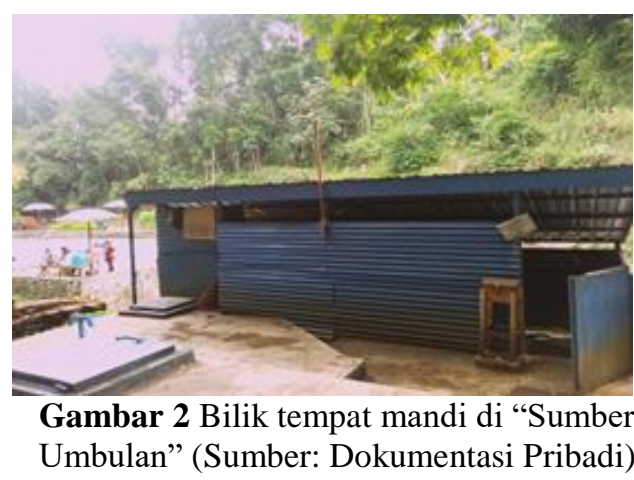

Seiring berjalannya waktu, "sumber umbulan" semakin ramai didatangi pengunjung yang tidak hanya berasal dari luar Kabupaten Malang saja, melainkan dari luar pulau Jawa yaitu Sumatera dan Bali. Melihat keadaan sumber yang semakin ramai pada tahun 2017-an, masyarakat Dusun Ubalan membentuk komunitas pengelola wisata untuk mengembangkan "sumber umbulan" menjadi wisata pemandian yang tetap menjunjung tinggi 
kesakralan dan unsur religinya dengan diberi nama wisata religi "sumber umbulrejo". Dalam mengembangkan "sumber umbulan", sumber dananya berasal dari dana masyarakat sendiri yang kemudian nanti dikembalikan lagi ke masyarakat dusun melalui hasil pariwisata. Mengenai hasil pariwisata tersebut, diperoleh dari aturan yang ditetapkan yaitu setiap pengunjung yang datang ke wisata religi "sumber umbulrejo" harus membayar karcis masuk sebesar Rp 3.000. Gambar 3 berikut merupakan loket karcis masuk wisata religi sumber umbulrejo.

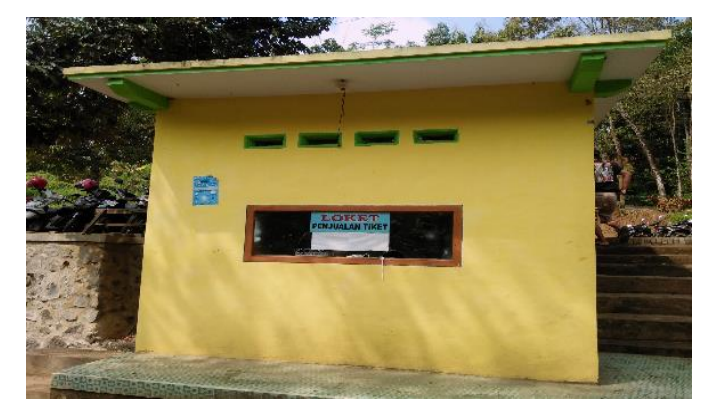

Gambar 3 Loket karcis di wisata religi "Sumber Umbulrejo” (Sumber: Dokumentasi Pribadi)

Selama satu tahun setelah "sumber umbulan" dijadikan sebagai wisata religi, tempat tersebut semakin dibanjiri pengunjung pada setiap harinya, apalagi pada hari-hari tertentu seperti malam Jumat legi, Selasa kliwon, dan bulan Selo yang dalam kalender masehi jatuh pada bulan Juni. Para pengunjung yang datang pada hari-hari tertentu percaya bahwa roh Eyang Sapu Jagad berada di sana untuk menambah kesakralan pada "sumber umbulan". Menurut Pak Fani selaku pengelola wisata, kepercayaan pengunjung terhadap kesakralan pada hari Jumat legi dan Selasa kliwon juga didukung oleh adanya layanan kunjungan di "sumber umbulrejo" yang dibuka sampai malam hari. Oleh karena hal itulah minat pengunjung yang datang semakin tinggi. Mengenai hal ini sesuai dengan yang disampaikan Pak Fani sebagai berikut.

"Kami sebagai pengelola wisata memberikan layanan kunjungan sampai malam hari pada hari khusus yaitu Jumat legi dan Selasa kliwon, jadi pengunjung dapat semalaman melakukan ritual mandi dan doa di sini. Layanan yang kami berikan ini berhasil menarik pengunjung datang karena bisa mencapai angka ratusan." (wawancara dengan Pak Fani, 1 Juni 2021 di Dusun Ubalan).

Tidak hanya itu, Pak Fani menambahkan bahwa ketertarikan pengunjung datang untuk memanjatkan doanya di wisata religi "sumber umbulrejo" disebabkan juga karena pada bulan Selo, selalu ada acara rutin pertunjukan wayang kulit dan kuda lumping yang bersifat sakral karena ditujukan untuk Eyang Sapu Jagad. Saat acara ini, seluruh masyarakat Dusun Ubalan melakukan ritual selamatan di sumber dengan dihadiri para pengunjung sebelumnya yang telah sukses karena hajatnya dikabulkan setelah memanjatkan doanya di "sumber umbulan". Dari adanya kegiatan tersebut secara tidak langsung semakin meningkatkan kepercayaan masyarakat baru yang berkunjung bahwa khasiat dari "sumber umbulan" yang dipercaya memiliki daya magis tinggi benar-benar nyata. Sehingga tidak menutup kemungkinan akan memunculkan narasinarasi masyarakat mengenai kesakralan mitos Eyang Sapu Jagad yang terus ditransmisikan (wawancara dengan Pak Fani, 1 Juni 2021 di Dusun Ubalan). Keberadaan wisata religi "sumber umbulrejo" yang semakin dikenal masyarakat luas, membuat pemasokan hasil wisata religi ini semakin besar karena adanya karcis masuk yang harus dibayar setiap pengunjung. Sehingga pada tahun 2018, pengelola wisata yang terdiri dari masyarakat Dusun Ubalan terus mengembangkan wisata religi pemandian ini dengan membangun sebuah kolam renang anak (gambar 4), beberapa destinasi kreatif spot foto, dan dilengkapi dengan tempat-tempat kuliner di dekat sumber tersebut (gambar 5). Strategi pengembangan wisata tersebut berhasil 
menarik minat pengunjung datang ke wisata religi "sumber umbulrejo" hingga mencapai kisaran 400-500 orang, utamanya pada hari libur. Pengunjung yang datang mulai tahun 2018 sangatlah bervariasi seperti berwisata ke kolam renangnya, menikmati keindahan alam yang disajikan, dan banyak yang melakukan ritual doa di petilasan "sumber umbulan". Hal ini sesuai dengan wawancara dengan Pak Fani sebagai berikut.

"Alhamdulillah sumber ini semakin ramai dikunjungi, kami selaku pengelola wisata berusaha mengembangkan wisata pemandian religi ini dengan membangun kolam renang anak, kuliner, tempat foto pada tahun 2018. Sejak itu pengunjung makin ramai, ada yang ritual di sumber, ada yang berenang saja, lihat pemandangan alam ya macem-macem. Kalau dirata-rata per harinya ya tidak tentu tapi dilihat pas hari-hari libur biasanya mencapai angka 400-500 an pengunjung." (wawancara dengan Pak Fani, 1 Juni 2021 di Dusun Ubalan).

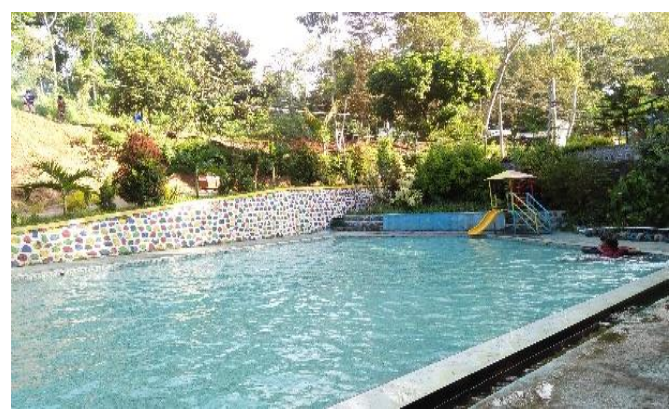

Gambar 4 Kolam renang anak di wisata religi "Sumber Umbulrejo" (Sumber: dokumentasi pribadi)

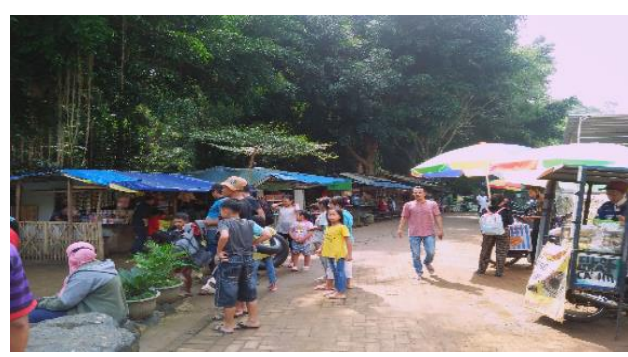

Gambar 5 Kuliner di wisata religi "Sumber Umbulrejo" (Sumber: dokumentasi pribadi)
Setahun setelah dibangunkannya kolam renang anak di samping petilasan "sumber umbulan", pengelola wisata membangun sebuah kolam renang lagi pada tahun 2019. Kolam renang kali ini dikhususkan untuk orang dewasa (gambar 6) karena dibuat dengan kedalaman sekitar $200 \mathrm{~cm}$. Kemudian pada tahun 2020, pengelola wisata semakin mengembangkan wisata religi "sumber umbulrejo" dengan membangun akses jalan menuju sumber (gambar 7). Tidak hanya itu saja, pengelola juga membangun lahan parkir (gambar 8) yang luas dengan menarik tarif kendaraan pengunjung, untuk roda dua sebesar Rp 3.000 sementara roda empat dengan tarif Rp 5.000. Terkait itu, berikut disajikan bukti adanya tempat tersebut.

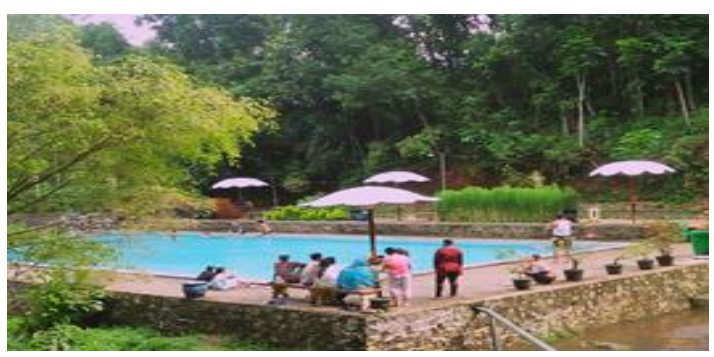

Gambar 6 Kolam renang dewasa di dekat "Sumber Umbulan" (Sumber: dokumentasi pribadi)

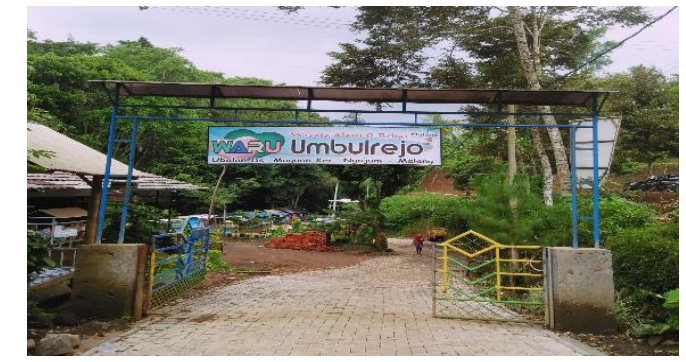

Gambar 7 Akses wisata religi "Sumber Umbulrejo" (Sumber: dokumentasi pribadi)

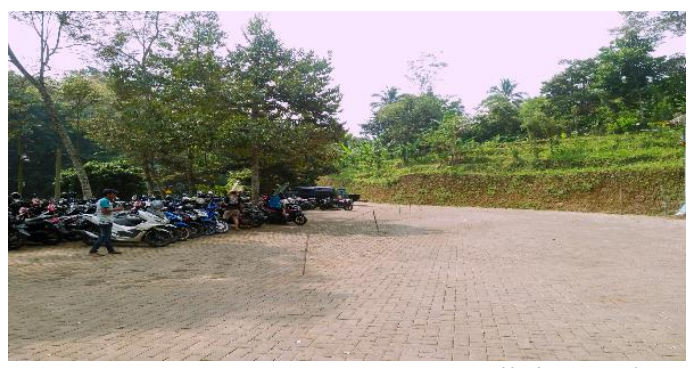

Gambar 8 Lahan parkir di wisata religi "Sumber Umbulrejo" (Sumber: dokumentasi pribadi) 
Berdasarkan hasil proses transformasi dari petilasan sakral "sumber umbulan" menjadi wisata religi "sumber umbulrejo" yang dilakukan pengelola wisata yang terdiri dari masyarakat Dusun Ubalan tersebut dapat dikatakan sebagai suatu proses komodifikasi. Seperti yang dikemukakan oleh Barker (2004) komodifikasi merupakan konsep yang tidak hanya berhubungan dengan produksi mengenai barang yang diperjualbelikan, tetapi juga mengenai bagaimana proses barang tersebut didistribusikan untuk dapat memenuhi kebutuhan konsumen. Pandangan ini sesuai dengan tindakan yang dilakukan masyarakat Dusun Ubalan, yang menggunakan produk komoditasnya berupa mitos Eyang Sapu Jagad melalui petilasan "sumber umbulan" yang didistribusikan dengan dibangunkannya sebuah pesarean dan bilik mandi dengan citra religi untuk memenuhi harapan konsumen yakni dapat melantunkan hajat-hajatnya dengan khusyuk.

Dalam mengkomodifikasikan wisata religi "sumber umbulrejo", pengelola wisata Dusun Ubalan memanfaatkan mitos Eyang Sapu Jagad sebagai bahan utama untuk menarik minat pengunjung. Hal ini membuktikan bahwa sastra berupa mitos berperan besar dalam menggerakkan industri pariwisata. Kondisi tersebut sesuai pandangan Herbert (1996) menurutnya tempat sastra berpotensi dapat menarik minat pengunjung karena makna atau nilai emosional tertentu yang telah melekat pada dirinya. Pandangan Herbert sesuai dengan keberadaan mitos Eyang Sapu Jagad yang memiliki esensi dan bernilai tinggi karena kesakralannya, sehingga mampu menarik minat pengunjung datang ke tempat mitos lahir. Oleh karena hal itulah petilasan Eyang berupa "sumber umbulan" dianggap memiliki daya tarik yang tinggi, sehingga keberadannya dikembangkan menjadi wisata religi. Tindakan yang sedemikian merupakan konstruksi sosial dari tempat sastra yang dikembangkan dan dipromosikan untuk menarik pengunjung (Herbert, 2001).

Banyaknya pengunjung yang datang ke wisata religi "sumber umbulrejo" dengan beragam motif telah membuktikan bahwa tempat tersebut dianggap berbeda dengan tempat lainnya karena dapat memenuhi keinginannya. Seperti pendapat Squire (1993) disusul pendapat Marsh (1993) mengatakan bahwa daya tarik pengunjung mungkin berasal dari kekagumannya terhadap sosok yang berhubungan dengan tempat sastra. Pandangan tersebut sesuai ketertarikan pengunjung yang datang ke wisata religi "sumber umbulrejo" karena mereka kagum terhadap kesaktian sosok Eyang Sapu Jagad sehingga percaya bahwa petilasan yang ditinggalkannya pasti memiliki kekuatan magis. Oleh karena kepercayaan yang tumbuh tersebut mengakibatkan banyak pengunjung yang datang dengan beragam tujuan seperti meminta kesaktian, kesembuhan, awet muda, naik jabatan dalam pekerjaannya, dan dilancarkan usahanya.

Adanya pertunjukan wayang kulit dan kuda lumping yang rutin dilakukan di wisata religi "sumber umbulrejo" pada bulan Selo merupakan salah satu aktivitas masyarakat yang menjunjung tinggi keberadaan mitos. Acara hiburan tersebut pada dasarnya ditujukan untuk mengukuhkan sakralitas petilasan Eyang Sapu Jagad, namun di satu sisi mampu menjadi daya tarik tersendiri bagi pengunjung untuk datang ke wisata religi "sumber umbulrejo". Kondisi yang sedemikian sesuai dengan pendapat Putra (2019) bahwa aktivitas yang diselimuti oleh sastra dengan kegiatan tertentu disebut sebagai festival sastra. Melalui festival sastra, keberadaan sastra turut menyumbang pengembangan pariwisata Indonesia. Oleh karena dampak festival sastra terhadap 
berbagai komponen dalam industri pariwisata seperti restoran, usaha akomodasi, penonton festival, dan makna festival bagi pencitraan destinasi mempengaruhi sektor pariwisata. Hal ini sesuai dengan festival sastra di wisata religi "sumber umbulrejo" yang secara otomatis menarik minat pengunjung datang dengan beragam tujuan seperti utamanya untuk melakukan ritual di sumber petilasan, menyaksikan dan menikmati pertunjukan, serta tidak menutup kemungkinan menikmati bermacam kuliner di wisata tersebut yang pada akhirnya berbagai fasilitas yang disediakan, dikonsumsi pengunjung karena sastra sebagai penggeraknya. Dengan demikian sangatlah jelas bahwa sastra telah praktik sebagai promosi pariwisata dalam segi sakral maupun profan.

Praktik sastra sebagai promosi pariwisata juga masih terlihat dari dampak pertunjukan wayang kulit dan kuda lumping yang rutin dilakukan pada bulan Selo. Hal ini disebabkan karena festival sakral tersebut dilakukan dengan acara slametan yang didatangi oleh para pengunjung sumber sebelumnya yang hajatnya telah dikabulkan. Dalam kondisi sedemikian secara tidak langsung, membuat pengunjung yang lain menjadi percaya bahwa kesaktian Eyang Sapu Jagad memang benar adanya, sehingga tidak menutup kemungkinan strategi retorika verbal mengenai narasi kesaktian petilasan Eyang Sapu Jagad ini dapat disebarluaskan dari masyarakat satu ke masyarakat lainnya. Kondisi tersebut sesuai pandangan Hughes (1992) bahwa tempat-tempat sastra yang dibentuk dalam citra pariwisata, dipromosikan dengan usaha para promotor menarik minat pengunjungnya melalui retorika komunikasi visual dan verbal. Retorika dilakukan dengan memanfaatkan nilai atau makna yang melekat lalu diolah dengan argumen kuat mengenai budaya historis sastranya untuk dimanipulasi sesuai dengan citra tertentu. Lebih lanjut (Herbert, 2001; Johnson, 1986) menyatakan bahwa kondisi sedemikian merupakan sajian konsumsi, karena pengunjung membentuk sikap dan kesan yang kemudian dapat mereka transmisikan kepada orang lain. Konsumsi ini dinamakan model sirkuit budaya dengan cara kerja di mana makna dikodekan oleh produsen atraksi dan diterjemahkan oleh pengunjung.

Komodifikasi mitos Eyang Sapu Jagad sebagai wisata religi "sumber umbulrejo" telah berhasil menunjang keberhasilan pariwisata di sana. Seperti yang dirumuskan (Ibrahim \& Akhmad, 2014; Mudana \& Ribek, 2017) komodifikasi barang yang dijual sesuai pangsa pasar dengan unsur religinya dapat menunjang keberhasilan wisata karena adanya pemasukan ekonomi. Konsep tersebut sesuai dengan keadaan wisata religi "sumber umbulrejo" di Dusun Ubalan yang telah dikomodifikasikan menjadi wisata dengan cara menetapkan loket penarikan karcis masuk setiap orang sebesar Rp 3.000, mampu menarik pengunjung dengan mencapai kisaran 500 orang pada hari-hari tertentu. Dengan adanya praktik ekonomi yang ditetapkan sebagai syarat yang harus dipenuhi pengunjung ke wisata "sumber umbulrejo", secara otomatis mampu mengantarkan keberhasilan praktik industri wisata religi tersebut dengan daya tariknya berupa mitos Eyang Sapu Jagad.

Strategi pengembangan wisata yang dilakukan pengelola di "sumber umbulrejo" dengan menyediakan layanan fasilitas pendukung berupa dua kolam renang telah berhasil menarik banyak pengunjung. Akan tetapi, dampak dari layanan pendukung tersebut mengakibatkan adanya keberagaman tujuan pengunjung yang berwisata, yakni tidak hanya untuk ritual saja namun ada yang berkunjung dengan tujuan hanya menikmati wisata kolam 
renangnya. Kondisi yang sedemikian menurut Herbert (1996) adalah dualitas ketertarikan umum dan khusus pengunjung yang harus diakui, karena esensi sastra sebagai daya tarik tempat wisata tidak selalu menjadi pengetahuan yang lazim dikonsumsi. Seperti pengunjung yang datang ke wisata religi "sumber umbulrejo" dengan tujuan berwisata saja adalah suatu hal wajar yang harus diakui. Apapun tujuannya, kedatangan pengunjung tidak dapat lepas dari praktik ekonomi pariwisata karena dapat dipastikan terdapat proses transaksi yang turut menyumbang sektor pariwisata.

\subsection{Tipe-tipe Pengunjung "Sumber Umbulrejo" Berdasarkan Motifnya}

Pada bagian ini dipaparkan hasil analisis tipe-tipe pengunjung berdasarkan motifnya mengunjungi wisata religi "sumber umbulrejo". Hasil penelitian menunjukkan bahwa pengunjung yang datang ke wisata religi "sumber umbulrejo" sesuai dengan teori yang dirumuskan Herbert (2001), yaitu adanya 1) pengunjung pilgrimis (memiliki minat \& pengetahuan khusus terhadap objek yang dikunjungi, dan 2) pengunjung generalis (tanpa memiliki pengetahuan khusus terhadap objek yang dikunjungi).

\subsubsection{Pengunjung Pilgrimis}

Pengunjung yang masuk kategori pilgrimis dengan memiliki minat dan pengetahuan khusus terhadap objek yang dikunjungi, saat penelitian dilakukan ditemukan tiga orang sebagai berikut. Pertama, Ibu Sutiyah berasal dari Talang Agung, Kabupaten Malang. Beliau berusia 68 tahun dengan keseharian sebagai ibu rumah tangga. Alasan $\mathrm{Bu}$ Sutiyah mengunjungi wisata religi "sumber umbulrejo" yaitu untuk melakukan ritual mandi, dengan harapan agar indra penglihatannya yang mengalami rabun dapat kembali normal dan penyakit gatalgatalnya lekas hilang. $\mathrm{Bu}$ Sutiyah mempercayai bahwa petilasan Eyang Sapu Jagad berupa "sumber umbulan" memiliki kekuatan magis yang dapat menyembuhkan berbagai penyakit. $\mathrm{Bu}$ Sutiyah juga mengatakan bahwa kedatangannya ke wisata religi "sumber umbulrejo" karena mendapat informasi dari tetangganya yang telah merasakan khasiat sumber setelah melakukan ritual di sana. Oleh karena beberapa hal itulah, beliau tertarik mendatangi "sumber umbulrejo" (wawancara dengan Ibu Sutiyah, 8 Mei 2021 di Dusun Ubalan).

Kedua, pengunjung yang berasal dari Surabaya bernama Mbak Sintia. Ia seorang pekerja swasta yang berusia 24 tahun. Adapun alasannya mengunjungi wisata religi "sumber umbulrejo" yaitu untuk melakukan ritual mandi dengan harapan agar selalu diberikan kesehatan. Mbak Sintia mempercayai adanya kekuatan magis dari petilasan Eyang Sapu Jagad karena salah satu anggota keluarganya yakni kakeknya telah hidup di masa kedatangan Eyang Sapu Jagad di Dusun Ubalan. Oleh karena narasi yang ditransmisikan kakeknya atas kesaktian dan ketaatan Eyang pada Tuhan selama hidupnya, membuat Mbak Sintia tertarik mendatangi "sumber umbulrejo" (wawancara dengan Mbak Sintia, 8 Mei 2021 di Dusun Ubalan).

Ketiga, pengunjung yang berasal dari Desa Ngasem, Kabupaten Malang, bernama Mas Arif. Ia berusia 21 tahun sebagai pekerja swasta. Alasannya mengunjungi wisata religi "sumber umbulrejo" untuk melakukan ritual doa di pesarean pada malam Jumat legi dengan tujuan mendoakan ruh Eyang Sapu Jagad, dengan disertai adanya harapan agar rezekinya semakin melimpah melalui perantara Eyang. Ia mengatakan bahwa sosok Eyang Sapu Jagad adalah seorang yang berjasa sehingga haruslah dikenang dengan cara 
terbaik yakni mengirimkan lantunan doa. (wawancara dengan Mas Arif, 8 Mei 2021 di Dusun Ubalan).

Dari hasil temuan di atas, terbukti bahwa keberadaan mitos Eyang Sapu Jagad sebagai daya tarik wisata religi "sumber umbulrejo", menjadi konsumsi utama masyarakat sampai saat ini. Kedatangan pengunjung tersebut didasari atas pengetahuan mereka terhadap mitos Eyang Sapu Jagad yang hidup di dalamnya. Mengenai hal ini sesuai dengan temuan $\underline{\mathrm{Yu}}$

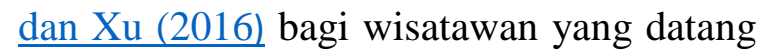
ke tempat pariwisata yang digerakkan oleh berbagai karya sastra, salah satunya puisi, mereka telah mengetahui keterkaitan budaya yang tersirat dalam puisi tersebut, sehingga menarik mereka datang ke tempat wisata sastra. Temuan ini tentu dapat disejajarkan dengan keberadaan sastra di Indonesia berupa mitos masyarakat yang secara tidak langsung berpotensi sebagai daya tarik wisata karena mampu menarik pengunjung yang datang dengan didasari atas pengetahuan budaya yang menyelimuti mitosnya. Pengunjung yang datang ke "sumber umbulrejo" telah mengetahui bahwa mitos ini merupakan hasil kebudayaan masyarakat Dusun Ubalan yang telah mengeramatkan petilasan sosok sakti bernama Eyang Sapu Jagad.

Ketertarikan pengunjung yang datang ke "sumber umbulrejo" didasari oleh rasa kagumnya terhadap sosok yang menjadi tokoh mitos di sana, sesuai dengan pendapat (Squire, 1993; Marsh, 1993) yang mengatakan bahwa daya pikat pengunjung dapat bermula dari kekagumannya terhadap sosok yang berhubungan dengan tempat sastra. Pandangan tersebut terlihat dari pengakuan Mbak Sintia dan Mas Arif, yang datang ke "sumber umbulrejo" karena pengetahuannya atas kehidupan sosok Eyang Sapu Jagad yang dulunya merupakan seseorang yang taat pada Tuhan. Mereka juga kagum atas kesaktian yang dimiliki
Eyang sehingga membuatnya percaya bahwa petilasan yang ditinggalkan memiliki energi sakral.

Kedatangan ketiga pengunjung yang menyatakan bahwa mendapati cerita dari orang lain mengenai kesakralan petilasan Eyang Sapu Jagad, membuktikan adanya pengaruh dari strategi retorika verbal dalam mentransmisikan keberadaan mitos. Sesuai pendapat Wulandari (2018) kemampuan berbicara seorang komunikator dengan menggunakan strategi tertentu dapat menimbulkan kesan memukau sehingga pesan yang disampaikan dapat mempengaruhi komunikan. Pandangan tersebut terlihat jelas dari pengakuan ketiga pengunjung yang menerima informasi tentang mitos Eyang Sapu Jagad dari komunikatornya masing-masing, yang kemudian membuat mereka datang ke petilasan mitos tersebut. Dengan tindakan tersebut terbukti bahwa pesan yang disampaikan komunikator melalui strategi khusus secara tidak langsung mampu mempengaruhi komunikannya. Hal ini dapat dikatakan sebagai praktik aktivitas pemasaran yang memanfaatkan strategi retorika (Suhandang, 2009).

\subsubsection{Pengunjung Generalis}

Pengunjung yang masuk kategori generalis dengan tidak memiliki pengetahuan khusus terhadap objek yang dikunjungi, saat penelitian berlangsung ditemukan dua orang sebagai berikut. Pertama, Ibu Siti Masruroh yang berasal dari Kota Malang. Beliau berusia 44 tahun dengan kesehariannya sebagai ibu rumah tangga. Adapun alasannya mengunjungi wisata religi "sumber umbulrejo" untuk menikmati liburan bersama keluarganya dengan berenang di kolam yang tersedia. $\mathrm{Bu}$ Siti juga mengatakan bahwa tujuannya datang hanya untuk liburan dan menikmati pemandangan alam saja, karena memang tidak tahu adanya mitos yang berkembang 
di tempat tersebut (wawancara dengan Ibu Siti Masruroh, 8 Mei 2021 di Dusun Ubalan).

Kedua, pengunjung yang berasal dari Dusun Ubalan, bernama Mbak Ayu. Ia berusia 30 tahun dengan keseharian sebagai pekerja swasta. Hasil wawancara dengan Mbak Ayu, ia mengatakan bahwa tujuannya datang hanya untuk menemani keluargnya berenang dan menikmati sajian kuliner di wisata religi "sumber umbulan". Ia juga menyatakan hal yang sama seperti Bu Siti Masruroh, yaitu tidak mengetahui tentang mitos yang tumbuh di tempat religi "sumber umbulrejo" (wawancara dengan Mbak Ayu, 8 Mei 2021 di Dusun Ubalan).

Dari hasil temuan tersebut, dapat dikatakan bahwa pengunjung yang datang ke wisata religi "sumber umbulrejo" ada yang tidak memiliki keterkaitan khusus dengan mitos Eyang Sapu Jagad, karena hanya ingin berwisata dengan menikmati fasilitasnya saja. Kondisi ini sesuai temuan Herbert (2001) bahwa tempat sastra yang terletak di lingkungan yang menyenangkan, terdapat pemandangan indah, dan memiliki fasilitas umum, dapat menarik wisatawan karena sajian tersebut, tanpa melirik sastra yang berkembang. Temuan tersebut selaras dengan temuan penelitian ini, yaitu adanya pengunjung yang datang ke wisata religi tanpa memiliki pengetahuan dan minat khusus terhadap objek sastranya, melainkan tertarik dengan kondisi lingkungan wisata "sumber umbulrejo" yang sangat mendukung dengan sajian pemandangan indah, kuliner, dan fasilitas kolam renang. Kondisi tersebut dapat dikatakan bahwa strategi pengembangan wisata religi "sumber umbulrejo" dengan adanya fasilitas kolam renang telah berhasil menjadi daya tarik tersendiri. Dengan demikian ketertarikan pengunjung yang datang tidak hanya terhadap mitosnya saja tetapi juga karena fasilitas pendukungnya telah sesuai harapan konsumen.

\section{Kesimpulan}

Keberadaan mitos Eyang Sapu Jagad di Dusun Ubalan, Kabupaten Malang telah berperan besar menggerakkan industri pariwisata. Hal ini karena petilasan Eyang Sapu Jagad berupa "sumber umbulan" di Dusun Ubalan telah dikomodifikasikan oleh pengelola wisata yang terdiri dari sekumpulan masyarakat Dusun Ubalan. Komodifikasi mitos didasari karena petilasan "sumber umbulan" selalu ramai dikunjungi masyarakat dengan beragam tujuan atas kepercayaannya terhadap kekuatan magis pada sumber. Komodifikasi dilakukan dengan mentransformasikan petilasan "sumber umbulan" menjadi wisata religi dengan nama "sumber umbulrejo". Dalam proses ini pegelola wisata menetapkan tarif pengunjung karena telah menyediakan fasilitas utama berupa pesarean dan bilik mandi yang dimaksudkan untuk memenuhi kebutuhan ritual konsumen serta memperkuat daya tarik pengunjung terhadap unsur wisata religinya. Daya tarik pengunjung semakin diperkuat dengan layanan kunjungan sampai malam hari pada malam jumat legi dan selasa kliwon untuk melakukan ritual di sumber. Serta adanya festival sastra yang rutin dilakukan di bulan Selo dengan pertunjukan wayang kulit dan kuda lumping juga menarik banyak pengunjung datang. Berbagai layanan yang disajikan tersebut secara tidak langsung menjadi strategi promosi untuk mengembangkan wisata karena berdampak terhadap usaha akomodasi di dalamnya yang turut menyumbang sektor pariwisata.

Adanya fasilitas utama yang disajikan sebagai tahap awal pengembangan wisata religi "sumber umbulrejo" telah berhasil menarik banyak pengunjung, membuat pengelola wisata terus mengembangkan tempat sastra dengan menyediakan berbagai fasilitas pendukung seperti dua kolam renang, tempat kuliner, destinasi kreatif spot foto, lahan parkir, dan akses jalan. Dengan strategi pengembangan tersebut, mengakibatkan adanya dualitas tipe pengunjung yang datang yakni 1) pengunjung pilgrimis dengan memiliki 
minat dan pengetahuan khusus terhadap objek yang dikunjungi yang terlihat dari motif kunjungan ingin sembuh dari penyakitnya dan dilimpahkan rezekinya, dan 2) pengunjung generalis, dengan tidak memiliki pengetahuan khusus yang terlihat dari kunjungan dengan tujuan berwisata semata untuk menikmati fasilitas kolam renang, sajian kuliner, dan pemandangan alam.

Berbagai temuan tersebut menunjukkan bahwa komodifikasi yang terjadi tidak menyebabkan hilangnya nilai kesakralan pada mitos, tetapi memperluas jaringan ekonomi-sosial masyarakat sekitar. Penelitian juga sekaligus memperlihatkan bahwa keberadaan mitos dalam kehidupan masyarakat tidak perlu selalu disikapi sebagai bentuk ketertinggalan cara berpikir, tetapi dengan pengelolaan kearifan lokal berbasis industri kreatif dapat meningkatkan taraf hidup masyarakat.

Penelitian ini hanya membahas tentang komodifikasi mitos Eyang Sapu Jagad sebagai promosi wisata dan daya tarik pengunjung di Kabupaten Malang. Saran untuk penelitian selanjutnya dapat membahas tentang pengaruh mitos Eyang Sapu Jagad terhadap identitas budaya masyarakat Dusun Ubalan, Kabupaten Malang.

\section{Daftar Pustaka}

Abdullah, R., \& Panghastuti, T. (2018). Analisis Hubungan Antara Bagunan Bersejarah, Mitos, Budaya Masyarakat Lokal dengan Motivasi Wisatawan Berkunjung di Daya Tarik Wisata Tamansari Yogyakarta. Journal of Tourism and Economic, 1(1). https://doi.org/10.36594/jtec.v1i1.20

Agfianto, T., Antara, M., \& Suardana, I. W. (2019). Dampak Ekonomi Pengembangan Community Based Tourism terhadap Masyarakat Lokal di Kabupaten Malang (Studi Kasus Destinasi Wisata Cafe Sawah Pujon Kidul). Jurnal Master Pariwisata (JUMPA), 259. https://doi.org/10.24843/jumpa.2018.v0 5.i02.p03

Andalas, E. F. (2015). Mitos-Mitos Kabupaten Malang: Cara Orang Jawa dalam Menjelaskan Dunianya. Jurnal Puitika, 11(2), 150-162. https://www.researchgate.net/profile/E ggy-Fajar-

Andalas/publication/323113958_Mitos -

Mitos_Kabupaten_Malang_Cara_Oran g_Jawa_dalam_Menjelaskan_Dunianya /links/5a804df64585154d57d8f458/Mit os-Mitos-Kabupaten-Malang-Cara-

Orang-Jawa-dalam-Menjelaskan-

Dunianya.pdf

Anoegrajekti, N., \& Imawati, E. (2020). Sastra Pariwisata: Dari Legenda Sampai Banyuwangi Ethno Carnival. Yogyakarta: PT Kanisius.

Aristama, M. F., Andalas, E. F., \& Sugiarti, S. (2020). Dampak dan Fungsi Mite Semar bagi Kehidupan Masyarakat Lereng Gunung Arjuna. Poetika, 8(1), 1-12.https://doi.org/10.22146 /poetika.55300.

Artawan, G. (2020). Aku Cinta Lovina: Peran Sastra dalam Mempromosikan Pariwisata Bali Utara. Jurnal Master Pariwisata (Jumpa), 241-256. https://doi.org/10.24843/JUMPA.2020 .v07.i01.p11

Badan Pusat Statistik (BPS) diakses dari https://malangkab.bps.go.id/publication /2021/02/26/d5bc23b51970236da8ea6f 8f/kabupaten-malang-dalam-angka2021.html, diakses pada tanggal 27 Mei 2021.

Barker, C. (2004). Cultural Studies: Teori \& Praktik, (Terjemahan Nurhadi). Yogyakarta: Kreasi Wacana.

Baudrillard, J. (2015). Masyarakat Konsumsi. Diterjemahkan oleh Wahyunto. Bantul: Kreasi Wacana. 
Busby, G., \& Klug, J. (2001). Movie-induced tourism: The challenge of measurement and other issues. Journal of Vacation Marketing, 7(4), 316-332. https://doi.org/10.1177/1356766701007 00403.

Effendy, C. (2019). Sastra Lisan Indonesia: Identitas Nasional, Karakter Bangsa, dan Ekonomi Kreatif. Makalah.

Febriyanto, A., Riawanti, S., \& Gunawan, B. (2018). Mitos Rambut Gimbal: Identitas Budaya dan Komodifikasi di Dataran Tinggi Dieng. Umbara, 2(1), $1-9$.

https://doi.org/10.24198/umbara.v2i1.1 5670

Herbert, D. (1996). Artistic and literary places in France as tourist attractions. Journal of Tourism Management, 17(2),77-85.

https://citeseerx.ist.psu.edu/viewdoc/do wnload?doi=10.1.1.457.1279\&rep=rep $1 \&$ type $=$ pdf

Herbert, D. (2001). Literary Places, Tourism and The Heritage Experience. Journal of Tourism Management, 28(2), 312333.https;doi.org/10.1016/S01607383(00)00048-7

Hughes, G. (1992). Tourism and the geographical imagination. Leisure Studies, 11(1), 31-42. https://doi.org/10.1080/0261436910039 0291

Humaeni, A. (2018). Moral Values in Religious Myths of Bantenese Society. Kawalu: Journal of Local Culture, 5(1), 1-16. http://dx.doi.org/10.32678/kawalu.v5i1 .2040

Ibrahim, I. S., \& Akhmad, B. A. (2014). Komunikasi dan Komodifikasi: Mengkaji Media dan Budaya dalam Dinamika Globalisasi. Yogyakarta: Yayasan Pustaka Obor Indonesia.
Jefrika, R. (2020). Gambaran Pariwisata di Kota Padang dalam Novel Sitti Nurbaya Karya Marah Rusli dan Pengaruh Novel Sitti Nurbaya terhadap Perkembangan Pariwisata Kota Padang Masa Kini. Disertasi. Padang: Universitas Andalas. http://scholar.unand.ac.id/61329/

Johnson, R. (1986). The Story So Far: And Further Transformations. In Introduction to Contemporary Cultural Studies, D. Punter, ed., pp. 277-313. London: Longman.

Marsh, K. (1993). Writers and Their Houses. London: Hamish Hamilton.

Mudana, I. W., \& Ribek, P. K. (2017). Komodifikasi Seni Lukis Wayang Kamasan Sebagai Produk Industri Kreatif Penunjang Pariwisata. Mudra Jurnal Seni Budaya,32(1), 68-80. https://doi.org/10.31091/mudra.v32i1.8 3

Pratiwi, Y., Andalas, E. F., \& Dermawan, T. (2018). Penelitian Sastra Kontekstual. Malang: Kota Tua.

Putra, I. N. D. (2019). Sastra pariwisata: pendekatan interdisipliner kajian sastra dan pariwisata. E-Proceeding Seminar Nasional INOBALI 2019, 2005, 173 181.file:///C:/Users/User/Downloads/1 60-Article\%20Text-329-1-1020200122\%20(3).pdf

Putra, I. N. D. (2019). Nuansa Bahasa dan Citra Sastra. Bali: Pustaka Larasan.

Renold, R., Teng, M. B. A., Anjarsari, H., \& Badollahi, M. Z. (2020). Pengembangan Destinasi Wisata Budaya Berdasarkan Mitos Sejarah dan Bangunan Kota Makassar Sulawesi Selatan (Studi Etnografi). Jurnal Pariwisata, 7(1), 1219.https://ejournal.bsi.ac.id/ejurnal/inde x.php/jp/article/view/5689/pdf 
Sudikan, S.Y. (2001). Metode Penelitian Sastra Lisan. Surabaya: Citra Wacana.

Suhamdani, H., Kadir, A. G., \& Irwan, A. L. (2010). Analisis pengembangan pariwisata alam lewaja Di Kabupaten Enrekang. Jurnal Administrasi Dan Kebijakan, 3, 8394.https://media.neliti.com/media/publi cations/100232-ID-analisis-

pengembangan-pariwisata-alam-le.pdf

Suhandang, K. (2009). Retorika: Strategi, teknik dan taktik berpidato. Bandung: Nuansa.

Sulistyorini, D., \& Andalas, E. F. (2017). Sastra Lisan: Kajian Teori dan Penerapannya dalam Penelitian. Malang: Madani.
Squire, S. J. (1993). Valuing Countryside: Reflections on Beatrix Potter Tourism. Journal of The Royal Geographical Society (with the Institute of British Geographers), 24(2), 5-10. https://www.jstor.org/stable/20003206

Wulandari, A. L. (2018). Strategi Retorika Verbal dan Nonverbal Karni Ilyas dalam Acara Indonesia Lawyers Club. Transformatika: Jurnal Bahasa, Sastra, Dan Pengajarannya, 2(2), 140. https://doi.org/10.31002/transformatika .v2i2.877

$\mathrm{Yu}, \mathrm{X} .$, \& Xu, H. (2016). "Ancient poetry in contemporary Chinese tourism". Journal of Tourism Management, 54, 393-403. https://doi.org/10.1016/j.tourman.2015. 12.007 